\title{
Effect of Previous Experience on Grazing Patterns and Diet Selection of Brangus Cows in the Chihuahuan Desert
}

\author{
Derek W. Bailey, ${ }^{1}$ Milton G. Thomas, ${ }^{2}$ John W. Walker, ${ }^{3}$ Barbara K. Witmore, ${ }^{4}$ and Doug Tolleson ${ }^{5}$
}

Authors are ${ }^{1}$ Associate Professor and ${ }^{2}$ Professor, Animal and Range Sciences, New Mexico State University, PO Box 30003, MSC 3-I, Las Cruces, NM 88003, USA; ${ }^{3}$ Professor and Resident Director, San Angelo Research and Extension Center, Texas AひM University, 7887 US Highway 87 North, San Angelo, TX 76901, USA; ${ }^{4}$ Graduate Research Assistant, Animal and Range Sciences, New Mexico State University, PO Box 30003, MSC 3-I, Las Cruces, NM 88003, USA; and ${ }^{5}$ Director, Grazinglands Animal Nutrition Laboratory, Texas A 6 M University, College Station, TX 77843, USA.

\begin{abstract}
The ability to adapt to different environments is critical when livestock are moved because of drought or other management considerations. The impact of previous experience on grazing patterns and diet selection of Brangus cows in desert conditions was evaluated. Cows originating from a humid-subtropical environment (Leona, Texas) were brought to the Chihuahuan Desert (naïve) and evaluated against cows that spent their life in the Chihuahuan Desert (native) and cows that were born and raised in the Chihuahuan Desert but were moved to Leona, Texas during the preceding 3 yr (tourist). In addition, native cows with recent experience in desert conditions were compared with naïve cows and tourist cows that had not been in the Chihuahuan Desert for at least $3 \mathrm{yr}$. All cows were mature and had similar pedigrees $(n=21)$. Cows from the three groups were tracked in three extensive pastures ( $>1000 \mathrm{ha}$ ) for three 8-10-d periods during winter, early summer, and later summer. Cows never grazed in the experimental pastures before the study, but native and tourist cows had grazed adjacent pastures. Fecal near-infrared spectroscopy was used to estimate diet quality. Naïve cows used 335 ha \pm 83 standard error (SE) less area $(P=0.06)$ and were $479 \mathrm{~m} \pm 105 \mathrm{SE}$ closer to water $(P=0.03)$ than cows born and raised in the Chihuahuan Desert (native and tourist cows pooled) when first evaluated in winter. After pooling all data, native cows were farther $(P=0.06)$ from water $(730 \mathrm{~m} \pm 283 \mathrm{SE})$ and spent less time at water $(10.53 \% \pm 3.93 \mathrm{SE}$ ) than cows that did not spend their entire life in the desert (naive and tourist pooled). During winter and early summer (drought conditions), naïve cows selected diets with lower $(P<0.05)$ crude protein $(\mathrm{CP})$ than cows born in the desert, but during late summer after abundant precipitation naïve cows selected a diet with higher $(P=0.07) \mathrm{CP}$. Although Brangus cows are highly adaptable, animals raised in nearby pastures appear to have advantages over naïve animals when grazing Chihuahuan Desert rangeland.
\end{abstract}

\section{Resumen}

La habilidad de adaptarse a diferentes ambientes es fundamental cuando se mueve ganado debido a la sequía o debido a otras consideraciones de manejo. Se evaluó el efecto de previa experiencia del ganado en patrones de pastoreo y selección de dieta de vacas Brangus en condiciones del desierto. Vacas procedentes de un ambiente húmedo subtropical (Leona, Texas) se llevaron al desierto Chihuahuense (ingenuas) y se compararon con vacas que pasaron su vida en el desierto Chihuahuense (nativas) y vacas que nacieron y se criaron en el desierto Chihuahuense, pero se trasladaron a Leona, Texas durante los tres años anteriores (turista). Además, las vacas locales con experiencia reciente en las condiciones del desierto se compararon con vacas sin experiencia y vacas turistas que no habían estado en el desierto Chihuahuense por lo menos durante 3 años. Todas las vacas eran maduras y tenían similares genealogías $(n=21)$. Se realizó un seguimiento de tres grupos de vacas en tres potreros bastante extensos ( $>1000$ hectáreas) por un periodo de 8-10 días durante el invierno, principios y finales del verano. Las vacas nunca pastorearon en los potreros experimentales antes del estudio, pero las vacas turistas y las inexpertas pastorearon en potreros adyacentes. Se utilizó espectroscopia infrarroja en muestras fecales para estimar la calidad de la dieta. Durante el invierno, las vacas inexpertas utilizaron 335 ha $\pm 83 \mathrm{SE}(P=0.06)$ y estuvieron $479 \mathrm{~m} \pm 105 \mathrm{SE}$ cerca del agua $(P=0.03)$ en comparación con vacas que nacieron y crecieron en el desierto Chihuahuense (combinación de vacas turistas e ingenuas). Después de combinar todos los datos, las vacas nativas estuvieron más lejos $(P=0.06)$ de los aguajes $(730 \mathrm{~m} \pm 283 \mathrm{SE})$ y dedicaron menos tiempo en los aguajes $(10.53 \% \pm 3.93 \mathrm{SE})$ que vacas que no pasaron toda su vida en el desierto (combinación de vacas inexpertas y turísticas). Durante el invierno y principios del verano (condiciones de sequia), las vacas inexpertas seleccionaron dietas con niveles más bajos $(P<0.05)$ de proteína cruda que las vacas que nacieron en el desierto, pero al final del verano después de precipitaciones abundantes las vacas sin experiencia seleccionaron una dieta con un contenido mayor $(P=0.07)$ de PC. Aunque las vacas Brangus son altamente adaptables, animales criados en pastizales cercanos parecen tener ventajas sobre los animales inexpertos en condiciones de pastoreo en el Desierto Chihuahuense.

Key Words: diet quality, distribution, experience, fecal near-infrared spectroscopy, GPS collars

This research is supported in part by the New Mexico Agricultural Experiment Station (Project NM-110000).

Correspondence: Derek Bailey, Animal and Range Sciences, New Mexico State University, PO Box 30003, MSC 3-I, Las Cruces, NM 88003, USA. Email: dwbailey@nmsu.edu

Manuscript received 10 December 2008; manuscript accepted 10 September 2009. 


\section{INTRODUCTION}

Livestock are often moved from one location to another because of drought or other management considerations. In some cases, animals are moved to areas with forages and environmental conditions that differ greatly from conditions to which they are accustomed. To perform satisfactorily in new locations, livestock must be able to adapt to new plants, topographical features, and locations of water. Early foraging experiences as calves may be an important determinant of the foraging patterns expressed as mature cows. Howery et al. (1996) determined that different cows grazed in different areas within extensive mountain pastures during summer and they used the same areas during the next four summers. Subsequently, grazing patterns of offspring from these cows were observed. When evaluated at 2 and $3 \mathrm{yr}$ of age, daughters preferred the areas that their mothers preferred (Howery et al. 1998). That study included a cross-fostering experiment where female calves from cows that preferred one area of the habitat (drainage) were reared by unrelated cows (foster mothers) that preferred a different habitat (adjacent drainage). Cross-fostered offspring preferred the areas where their foster mother reared them. Consequently, naïve animals may not be able to forage as efficiently in novel areas as animals that have experience in that environment. Moving livestock to unfamiliar areas and conditions often results in animals spending more time grazing but with lower total forage intake rates (Provenza 2003).

The first objective of this study was to compare grazing distribution patterns and quality of selected diets of Brangus cows that were familiar with the Chihuahuan Desert to Brangus cows that were naïve to desert conditions and were accustomed to a subtropical environment. The second objective was to determine if Brangus cows that were raised in Chihuahuan Desert conditions but were later moved to a subtropical environment for $3 \mathrm{yr}$ would have similar movement patterns and diet quality compared to Brangus cows that remained in the Chihuahuan Desert their entire lives.

\section{MATERIALS AND METHODS}

The procedures used in this study were approved by the New Mexico State University Institutional Animal Care and Use Committee.

\section{Study Site}

The study was conducted at the Chihuahuan Desert Rangeland Research Center (CDRRC) located $37 \mathrm{~km}$ north of Las Cruces in south-central New Mexico (lat $32^{\circ} 32^{\prime} \mathrm{N}$; long $106^{\circ} 48^{\prime} \mathrm{W}$ ). Soils are primarily fine sandy loams underlain by calcium carbonate hardpans at depths varying from a few centimeters to greater than $1 \mathrm{~m}$.

Climatic conditions at the CDRRC are typical of the Chihuahuan Desert with a 74-yr mean annual precipitation of $234 \mathrm{~mm}$. About $52 \%$ of the precipitation occurs during the primary growing season of July-September. Temperatures in the summer are high, with a mean maximum temperature of $36^{\circ} \mathrm{C}$ during June, and the mean maximum temperature in January is $13^{\circ} \mathrm{C}$. Mean minimum temperature for January is $-3^{\circ} \mathrm{C}$ and $16^{\circ} \mathrm{C}$ for June. From November 2005 through June

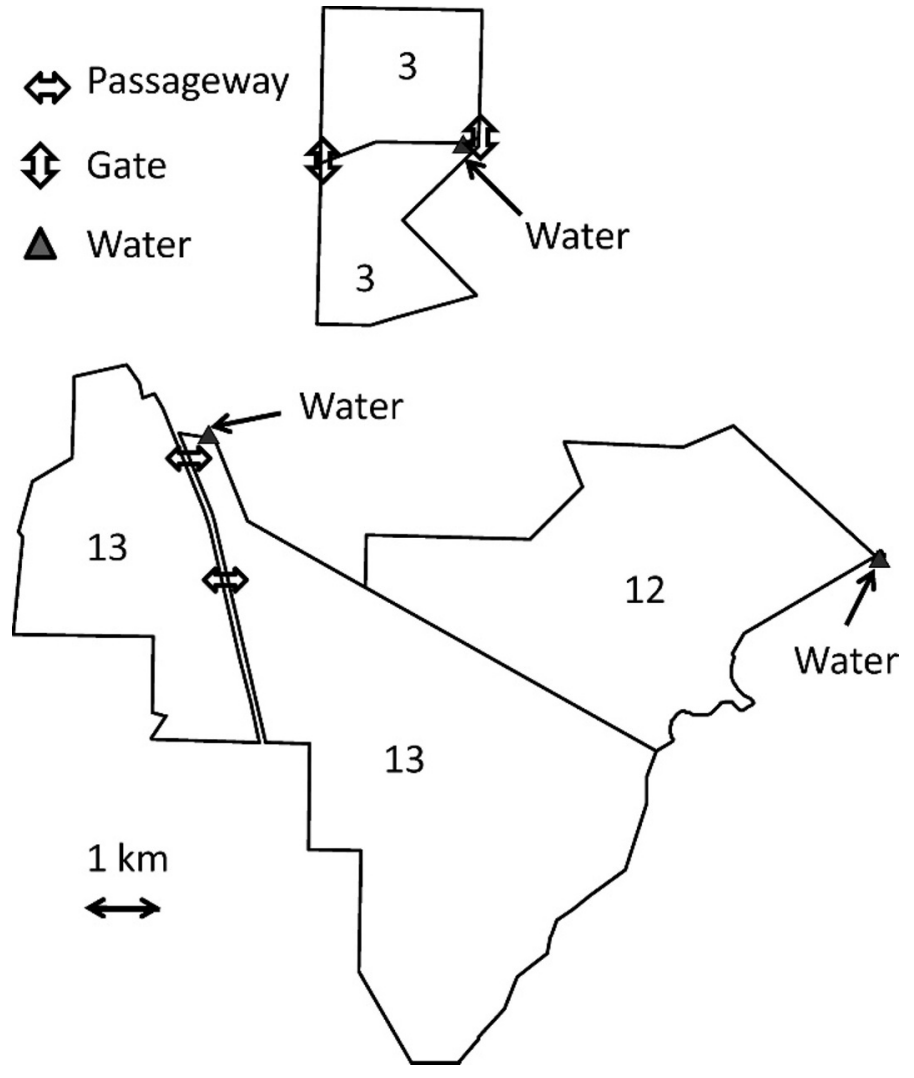

Figure 1. Map of pastures 3, 12, and 13 used in the study. Water was available in only one location in each pasture. Pasture 3 was bisected with a fence but gates on the ends of the division were open. Pasture 13 was bisected by Interstate Highway 25, but there were two tunnels ( $5 \mathrm{~m}$ wide and $6 \mathrm{~m}$ high) that allowed cattle to pass freely into either subdivision. Pastures 3, 12, and 13 enclosed 1002 ha, 1859 ha, and 3770 ha, respectively.

2006, conditions were unusually dry, with only $22 \mathrm{~mm}$ of precipitation. However, during July-September 2006, rainfall was uncommonly high, with $355 \mathrm{~mm}$ of precipitation. Mean maximum and minimum daily temperatures during winter observations (mid-January to early February) were $15.8^{\circ} \mathrm{C} \pm 3.2$ standard deviation $(\mathrm{SD})$ and $0.0^{\circ} \mathrm{C} \pm 3.5 \mathrm{SD}$, respectively. During early summer observations (mid-May to early June), mean maximum and minimum daily temperatures were $34.3^{\circ} \mathrm{C} \pm 2.9$ $\mathrm{SD}$ and $18.2^{\circ} \mathrm{C} \pm 2.7 \mathrm{SD}$, respectively. Mean maximum and minimum daily temperatures during late summer observations (mid-August to early September) were $29.6^{\circ} \mathrm{C} \pm 4.1 \mathrm{SD}$ and $19.6^{\circ} \mathrm{C} \pm 1.7 \mathrm{SD}$, respectively.

Dominant grasses in the study pastures are dropseeds (Sporobolus spp.), three awns (Aristida spp.), and black grama (Bouteloua eriopoda [Torr.] Torr.). Common shrubs are honey mesquite (Prosopis glanulosa Torr.), broom snakeweed (Guiterrezia sarothrae [Pursh] Britton \& Rusby), and creosote bush (Larrea tridentata [Sesse' \& Moc. ex DC.] Coville).

Three pastures $(3,12$, and 13) were used in the study. All three pastures had only one water source (Fig. 1). Pasture 3 was formed by opening the two gates separating pastures $3 \mathrm{~N}$ and $3 S$. This resulted in a 1002 -ha pasture with a gentle terrain and a maximum distance from water of $3.4 \mathrm{~km}$. Gates were at each end of the division fence, and one gate was approximately 
$300 \mathrm{~m}$ from water. Pasture 12 was 1859 ha with a maximum distance from water of $7.9 \mathrm{~km}$. Terrain was generally gentle with some alluvial outflow areas (bajada) with slopes varying from $1 \%$ to $16 \%$. Pasture 13 contained 3770 ha of variable topography with a maximum distance from water of $10.2 \mathrm{~km}$. Terrain in Pasture 13 was generally rolling, with a series of small ridges and arroyos with slopes usually varying from $1 \%$ to $10 \%$. The perennial grass standing crop available for cattle to graze was estimated in each pasture at the beginning of the study, January 2006, and at the end of the study, August 2006. Ten to $150.5-\mathrm{m}^{2}$ frames were clipped in each pasture. Harvested forage was dried for $48 \mathrm{~h}$ at $50^{\circ} \mathrm{C}$, ground to pass a 1-mm screen, and analyzed for crude protein (CP), neutral detergent fiber, and acid-detergent fiber.

\section{Animals}

The study compared three groups of mature Brangus cows (3$10 \mathrm{yr}$ of age) registered with International Brangus Breeders Association (San Antonio, Texas). Cows had similar ancestry in their three-generation pedigrees. One group (naïve) had not been to the Chihuahuan Desert before the study and had lived in a subtropical environment (1040 $\mathrm{mm}$ average precipitation) at Mound Creek Ranch near Leona, Texas (lat $31^{\circ} 08^{\prime} \mathrm{N}$, long $\left.95^{\circ} 52^{\prime} \mathrm{W}\right)$. In this management system, pastures averaged less than 33 ha in size and were dominated by bermudagrass (Cynodon dactylon [L.] Pers.) and partially forested. A second group (native) had been raised at the CDRRC and remained there before and during the study. The third group (tourist) was moved from the CDRRC to Leona, Texas in 2002 because of limited forage availability resulting from drought. These cows remained in Leona, Texas for $3 \mathrm{yr}$ and were returned to the CDRRC immediately before the study. All cows calved in late February or March 2006 and calves were weaned at the end of the study in early September 2006. Prior to the study, all cows had not grazed in the three study pastures at the CDRRC. The tourist and native groups grazed pastures adjacent to study pastures. Naïve cows had never been to the CDRRC before the study. Naïve and tourist cows were fed hay in pens at the New Mexico State University campus in Las Cruces, New Mexico for the 10-d interim between being moved from Leona, Texas and beginning the study at the CDRRC. Each group consisted of seven randomly selected cows from the available animals with that background. These three groups of seven cows were used throughout the study.

\section{Design and Protocol}

The three groups of cows were compared and evaluated during three different sessions. Each session lasted 28-30 d. The first session (winter) began 9 January 2006, before calving. The second session (early summer) began 10 May 2006, after calving, during early lactation. The third session (late summer) began 8 August 2006, during late lactation. Each group of cows grazed in each of the three study pastures during each session. Cows remained in each pasture for a period of 8-10 d (three periods per session).

The experimental design was a $3 \times 3$ Latin-square design in which the experimental unit was the combination of the three pastures grazed during three different periods. Cows from three treatment groups that represented different experiential histo- ries were randomly assigned to experimental units (pasture and period combinations). Periods were purposely kept short (8$10 \mathrm{~d}$ ) with no interim between periods, and stock densities were extremely light (range 143-539 ha/cow) to keep forage conditions in a pasture within a session as similar as possible. Stocking rates in a pasture during a session were roughly 7 animal unit months (AUMs) while the Natural Resources Conservation Service (2009) initial suggested stocking rates for pastures 3, 12, and 13 were approximately 412, 656, and 621 AUMs, respectively. Short periods and light stocking rates should minimize, if not eliminate, biases resulting from differences in forage conditions between pastures.

During the interim between the winter session and the early summer session, groups were kept in separate pens and fed hay. During the interim between the early summer session and late summer sessions, groups remained separated and grazed separate pastures at the CDRRC that were adjacent to the study pastures. Cows were weighed at the beginning of each session and end of each $8-10-d$ period. Body condition score ratings using a $1-9$ scale $(1=$ emaciated and $9=$ obese $)$ were recorded at the beginning of each session (Mathis et al. 2002). Cows were pregnancy tested after the study on 12 September 2006 by rectal palpation. Calves of cows in the study were weighed and weaned on 12 September 2006. Weaning weights were also adjusted to an age constant basis of $205 \mathrm{~d}$ (Beef Improvement Federation 2002). A bull grazed with each group of cows from the beginning of the early summer session to the beginning of the late summer session (90 d).

\section{GPS Tracking}

One randomly selected cow from each group was tracked with global positioning system (GPS) collars. During the JanuaryFebruary session cows were tracked with WTIGPS 500b collars (Wildlife Track Inc., Caldwell, ID) that recorded the position every $30 \mathrm{~min}$, which is equivalent to 48 positions per day. The WTIGPS collars were differentially corrected with the use of information obtained from the Wide Area Augmentation System that is provided by the Federal Aviation Administration. During the early summer (May-June) and late summer (August-September) sessions, cows were tracked with Lotek GPS 3300 collars (Lotek Wireless, Newmarket, Ontario, Canada) at 10-min intervals, equivalent to 144 positions per day. Positions from the Lotek GPS 3300 collars were differentially corrected with the use of the postprocessing features Lotek N4 v.1.1895 software (Lotek). Reference base station data were obtained from a site at New Mexico State University campus in Las Cruces, New Mexico approximately $35 \mathrm{~km}$ from the study pastures. After differential correction, accuracy of recorded locations is within $7 \mathrm{~m}$ (Moen et al. 1997). More recently, Ganskopp and Johnson (2007) found that differential correction reduced the mean bias of GPS positions from roughly $4 \mathrm{~m}$ to $2 \mathrm{~m}$. With the large scale of this study, differential correction was used to improve, at least to some degree, accuracy of estimates of distance traveled by cows each day, visits to water, and other parameters used to describe cattle grazing patterns. In addition to GPS tracking, observers located and recorded positions of all cows two or three times each week to determine if positions of collared cows were similar to other cows in the group. 
Distance from water was calculated for each recorded position and averaged for each period. For each of the three periods, the maximum distance from water and area enclosed by the minimum convex polygon encompassing all recorded positions of a collared cow was calculated. Distance traveled was calculated by summing distance between successive cow locations and dividing by number of days cows were tracked. Distance traveled calculated from positions recorded at $30-\mathrm{min}$ intervals during the winter session is expected to be lower in value and less precise than from travel distances from early and late summer sessions (Johnson and Ganskopp 2008), which were recorded at 10 -min intervals. Although 30-min intervals were less accurate and precise than 10-min interval data, the calculated distance traveled calculated from the 30-min interval data should be useful for evaluating relative differences in the treatment groups when evaluated within that session.

\section{Diet Quality Sampling}

Fecal samples were collected from each cow at the end of each period. In addition, fecal samples were collected after cows were fed sudan grass (Sorghum vulgare var. Sudanense, Hitch.) hay harvested from the same field at the same time for $10 \mathrm{~d}$ during the interim between the winter and early summer sessions. At the end of the study, all cows were fed sudan grass hay in the same pen, and fecal samples were collected after $7 \mathrm{~d}$. The purpose of collecting fecal samples after cows were fed hay was to confirm that diet quality estimates used in the study were similar among cows when fed the same diet.

Fecal samples were frozen, dried, and ground in a Wiley mill to pass a 1-mm screen. Fecal samples were ground a second time in a cyclone mill to pass through a 1-mm screen, dried in a forced-air oven $\left(50^{\circ} \mathrm{C}\right.$ for $\left.12 \mathrm{~h}\right)$, and conditioned for $24 \mathrm{~h}$ in an environment with constant temperature and humidity $\left(21^{\circ} \mathrm{C}\right.$, $65 \%)$. Approximately $4 \mathrm{~g}$ of ground, conditioned samples were packed in quarter-cup sample cells with a near-infrared, transparent, quartz cover glass. Cells were scanned 32 times with the use of a scanning reflectance monochromator (model 6500, NIR Systems Inc., Silver Springs, MD). Reflected energy $(\log [1 / \mathrm{R}]$, where $\mathrm{R}=$ reflectance) was measured and averaged over the 32 scans and recorded at 2-nm intervals from 1100 to $2500 \mathrm{~nm}$. Diet CP and digestible organic matter (DOM) during a period were determined using equations originally developed by Lyons and Stuth (1992) and later expanded by Stuth (unpublished).

\section{Statistical Analyses}

Grazing Patterns. The experimental unit used in this study was the combination of pasture $(3,12$, and 13$)$ and period $(1$, 2 , and 3), which resulted in nine observations for comparisons of the three cattle groups with different experiences during a session. Dependent variables evaluated included average distance from water, maximum distance from water, minimum area used, distance traveled, trips to water, time at water, time away from water, and percent of time spent at water. Separate analyses were conducted for all dependent variables during each session (winter, early summer, and late summer) with the use of a model that included experience (naïve, native, or tourist), pasture, and period ( $n=9$ and error $\mathrm{df}=2$ ).
The combined data set from all three sessions was evaluated with the use of repeated-measures procedures of PROC MIXED (SAS 2002). The model included experience, session, pasture, period, and session by experience interaction as fixed effects. The repeated term used pasture by experience interaction as the subject, and covariance between repeated records was modeled using autoregressive of order 1, autoregressive with heterogeneous variance, compound symmetry, compound symmetry with heterogeneous variance, or unstructured covariance structures (Littell et al. 1996). Of the five covariance structures evaluated, the structure resulting in the lowest Akaike's Information Criterion value was selected.

Single-degree-of-freedom orthogonal contrasts were used to compare naïve cows to cows from the CDRRC (native and tourist pooled). Naïve cows had no experience with Chihuahuan Desert conditions early in life, whereas native and tourist cows were born and raised at the CDRRC. Early experience can have long-lasting impacts on livestock diet selection and movement patterns (Provenza and Balph 1988; Howery et al. 1998). Single-degree orthogonal contrasts were also to differentiate native cows that had recent experience in desert conditions to cows that had not been in the Chihuahuan Desert for at least $3 \mathrm{yr}$ (naïve and tourist pooled). Bailey and Provenza (2008) suggest that recent experience can potentially affect both diet selection and grazing patterns. In addition to orthogonal contrasts, differences in individual least-squares means were determined with the use of PDIFF function of LSMEANS in PROC MIXED (SAS 2002).

Cow Weights. A repeated-measures analysis with PROC MIXED (SAS 2002) was also used to evaluate weight changes of cows. Fixed effects included experience, session, period within session, and session by experience as fixed effects. The interaction of experience, pasture, and period was used as a random variable and error term for testing for differences in experience and cow within experience was the repeated term. Compound symmetry was selected to model the covariance structure using the procedures described above.

Diet Selection. Each session was analyzed separately for diet quality (DOM and CP). Values for each cow were analyzed with PROC MIXED (SAS 2002) with a mixed model (Littell et al. 1996) where experience (naïve, native, and tourist), pasture, and period were fixed effects and the interaction between experience, pasture, and period was considered random and used as the error term $(n=9$, error $\mathrm{df}=2)$. Diet-quality data from each session were not analyzed together, because there was an obvious experience by session interaction.

\section{RESULTS}

\section{Forage Quality and Standing Crop}

Perennial grasses at the beginning of the study were of low quality (Table 1). During the last session (late summer), crude protein concentration of perennial grasses averaged $12.4 \%$ and only $5.5 \%$ during the first two sessions. Standing crop of perennial grasses during the first two sessions was less than $150 \mathrm{~kg} \cdot \mathrm{ha}^{-1}$. During the last session, standing crop of perennial grasses was less than $150 \mathrm{~kg} \cdot \mathrm{ha}^{-1}$, but annual forbs and grasses $\left(46-186 \mathrm{~kg} \cdot \mathrm{ha}^{-1}\right)$ were available. There was 
Table 1. Quantity and quality of perennial grasses in the study pastures at the beginning and end of the study.

\begin{tabular}{|c|c|c|c|}
\hline \multirow[b]{2}{*}{ Attribute $^{1}$} & \multicolumn{3}{|c|}{ Pasture } \\
\hline & 3 & 12 & 13 \\
\hline \multicolumn{4}{|l|}{ Beginning, winter session } \\
\hline $\mathrm{CP}, \%$ & 6.3 & 5.3 & 5.0 \\
\hline ADF, $\%$ & 43.6 & 42.7 & 44.5 \\
\hline NDF, $\%$ & 66.1 & 66.4 & 67.9 \\
\hline Perennial grass standing crop, $\mathrm{kg} \cdot \mathrm{ha}^{-1}$ & 82 & 110 & 90 \\
\hline \multicolumn{4}{|l|}{ End, late summer session } \\
\hline $\mathrm{CP}, \%$ & 9.3 & 15.0 & 12.9 \\
\hline ADF, \% & 42.6 & 37.9 & 49.2 \\
\hline NDF, $\%$ & 66.2 & 62.9 & 62.5 \\
\hline Perennial grass standing crop, $\mathrm{kg} \cdot \mathrm{ha}^{-1}$ & 105 & 50 & 11 \\
\hline Annuals ${ }^{2}, \mathrm{~kg} \cdot \mathrm{ha}^{-1}$ & 186 & 89 & 46 \\
\hline
\end{tabular}

virtually no annual vegetation present during the winter and early summer sessions.

\section{Cow and Calf Performance}

Weight changes of cows during the study were not affected by experience $(P=0.94)$. Overall, the mean weight of cows at the beginning of the study was $601 \mathrm{~kg} \pm 14 \mathrm{SE}$ and $528 \mathrm{~kg} \pm 10 \mathrm{SE}$ at the end of the study (Table 2). Cow weight varied across sessions $(P=0.05)$. Cow weight did not change greatly during the winter $(-5 \mathrm{~kg} \pm 6 \mathrm{SE})$ and late summer $(6 \mathrm{~kg} \pm 7 \mathrm{SE})$, but cows lost weight in early summer $(-20 \mathrm{~kg} \pm 6 \mathrm{SE})$. After the study on 12 September 2006, all of the native cows $(100 \%)$ were pregnant. Only $43 \%$ of the tourist cows were pregnant, and $67 \%$ of the naive cows were pregnant.

The average actual weaning weight of calves from naïve cows was $161 \mathrm{~kg} \pm 11 \mathrm{SE}$. The calves from tourist cows averaged $188 \mathrm{~kg} \pm 11 \mathrm{SE}$, while calves from the native cows averaged $218 \mathrm{~kg} \pm 8$ SE. The average 205-d age-adjusted weaning weight was $196 \mathrm{~kg} \pm 6 \mathrm{SE}$ for the naïve group and $202 \mathrm{~kg} \pm 13 \mathrm{SE}$ for the tourist group. For the native group, the $205-\mathrm{d}$ age-adjusted weaning weight was $234 \mathrm{~kg} \pm 8$ SE.

\section{Visual Observations}

Cows within a pasture were always observed within a group. Usually ( $>80 \%$ of observations) cows were within $40 \mathrm{~m}$ of each other. Cows within a pasture were never observed more than $100 \mathrm{~m}$ from another cow in the pasture.

\section{GPS Tracking}

Winter Distribution Patterns. When averaged over the entire winter session (Fig. 2), native cows were $635 \mathrm{~m} \pm 105 \mathrm{SE}$ farther from water $(P=0.03)$ than the other two groups (naïve and tourist pooled). When the naïve cows were first released during the winter session, they did not travel more than $300 \mathrm{~m}$ for 8 consecutive days even though the pasture was 3994 ha in size. The maximum distance traveled from water by naïve cows
Table 2. Mean ( $\pm \mathrm{SE}$ ) initial weights and body condition scores (BCS) and least-squares means ( $\pm \mathrm{SE}$ ) of weight changes during 28-30-d sessions of naïve, native, and cows that were moved away from the Chihuahuan Desert for 3 yr (tourist) during the winter (January-February 2006), early summer (May-June 2006), and late summer (AugustSeptember 2006).

\begin{tabular}{lrcc}
\hline & \multicolumn{3}{c}{ Experience } \\
\cline { 2 - 4 } Attribute & \multicolumn{1}{c}{ Naïve } & Native & Tourist \\
\hline Winter session & & & \\
Initial weight, $\mathrm{kg}$ & $609 \pm 13$ & $630 \pm 35$ & $565 \pm 13$ \\
Weight change, $\mathrm{kg}$ & $1 \pm 11$ & $-12 \pm 11$ & $-3 \pm 11$ \\
Initial BCS & $4.9 \pm 0.2$ & $5.2 \pm 0.1$ & $5.0 \pm 0.0$ \\
Early summer session & & & \\
Initial weight, kg & $618 \pm 13$ & $608 \pm 29$ & $557 \pm 17$ \\
Weight change, kg & $-27 \pm 11$ & $-15 \pm 11$ & $-19 \pm 11$ \\
Initial BCS & $4.5 \pm 0.2$ & $4.6 \pm 0.1$ & $4.4 \pm 0.2$ \\
Late summer session & & & \\
Initial weight, $\mathrm{kg}$ & $507 \pm 17$ & $491 \pm 16$ & $536 \pm 20$ \\
Weight change, $\mathrm{kg}$ & $10 \pm 11$ & $10 \pm 11$ & $-3 \pm 11$ \\
Initial BCS & $4.3 \pm 0.3$ & $4.4 \pm 0.2$ & $4.4 \pm 0.3$ \\
\hline
\end{tabular}

during the winter session was $2070 \mathrm{~m} \pm 214$ SE less $(P=0.01)$ than the other two groups that were raised at the CDRRC (Fig. 3). The naïve cows also occupied 335 ha \pm 83 SE less area than the pooled value for the native and tourist cows $(P=0.056)$ with the use of a minimum convex polygon approach (Fig. 4). The native cows were similar to the pooled naive and tourist cows for maximum distance traveled from water and area occupied $(P>0.20)$.

Early Summer Distribution Patterns. The naïve cows remained closer to water $(P=0.10)$ over the early summer session than cows raised at the CDRRC (native and tourist groups pooled). The difference in distance from water between the naïve cows and cows raised at the CDRRC was $621 \mathrm{~m} \pm 214$ SE. The maximum distance traveled to water was similar $(P=0.92)$ among the native, tourist, and naïve groups of cows (Fig. 3), and all groups used similar-sized areas $(P=0.44)$ within the pastures (Fig. 4).

Late Summer Distribution. The native cows remained farther from water $(P=0.10)$ during the late summer session than cows that did not spend their entire life at the CDRRC (tourist and naive cows pooled). The average distance from water differed between the native cows and the other two groups of cows by $967 \mathrm{~m} \pm 332 \mathrm{SE}$. The maximum distance traveled from water was similar $(P=0.19)$ for all cows, and the area used did not differ $(P=0.60)$ between the native, tourist, and naïve groups (Figs. 3 and 4).

Distribution Over All Sessions. When data from all three sessions were combined, native cows remained farther $(P=0.06)$ from water $(730 \mathrm{~m} \pm 283 \mathrm{SE})$ than cows that did not spend their entire life in the Chihuahuan Desert (Fig. 2). The maximum distance traveled from water by naïve cows was $765 \mathrm{~m} \pm 266 \mathrm{SE}$ less $(P=0.05)$ than for cows raised in the Chihuahuan Desert (Fig. 3). Cows raised in the Chihuahuan 


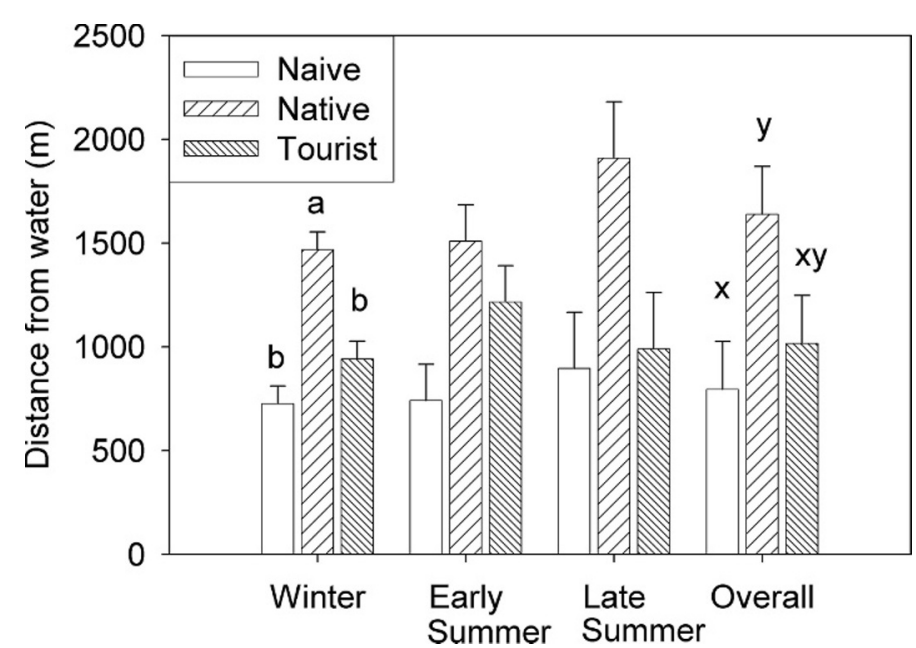

Figure 2. Average distance from water of global positioning system (GPS)-collared cows that were born and raised in a subtropical area (naïve), raised and remained in the Chihuahuan Desert (native), and were born and raised in the desert but were moved to a subtropical area for 3 yr prior to the study (tourist). Distances represent means from all GPS locations recorded for randomly selected cows in each group during 8$10-d$ periods in each pasture during the winter (January and early February 2006), early summer (May and early June 2006), and late summer (August and early September 2006) sessions. Data from all three sessions were pooled and evaluated with the use of a repeatedmeasures analysis to provide an indication of an overall response. Values with different letters within a session differ $(a, b, P<0.05$ or $x, y$, $P<0.10)$. Error bars represent standard error.

Desert used 166 ha \pm 40 SE more area $(P=0.05)$ than naive cows over the entire study. As shown by the treatment by session interaction $(P=0.04)$, the largest difference in area used occurred during the winter, and in the last session area used by each group was more similar (Fig. 4).

Distance Traveled. Experience did not affect $(P=0.20)$ the distance traveled by cows each day during any of the sessions (Table 3). Similarly, distance traveled was not affected by experience when evaluated over all three sessions $(P=0.69)$. Distance traveled was less in the winter session $(P<0.001)$ when positions were recorded at 30-min intervals compared to the early and late summer sessions when locations were recorded at 10 -min intervals.

Visits to Water. Cattle made fewer trips per day to water $(P=0.01)$ during the winter session $\left(1.09\right.$ trips $\cdot$ day $^{-1} \pm 0.13$ SE) than the early summer session (1.60 trips $\cdot$ day $^{-1} \pm 0.13$ $\mathrm{SE})$. Trips to water during late summer was intermediate (1.36 trips $\cdot$ day $\left.^{-1} \pm 0.13 \mathrm{SE}\right)$. Cows spent less time during a given visit to water $(P=0.10)$ during the late summer session than during winter and early summer (Table 3 ). Cows spent a smaller $(P=0.02)$ percentage of their time at water during late summer $(18.99 \% \pm 4.73 \mathrm{SE})$ than during early summer $(36.02 \% \pm 3.59 \mathrm{SE})$. The winter session was intermediate for the percentage of time cows were at water $(29.91 \% \pm 7.77 \mathrm{SE})$.

The number of trips cattle made to water each day was not affected by experience $(P>0.15)$ during any session or when pooled across sessions (Table 3 ). Experience did not affect the time cattle spent at water during a visit $(P>0.15)$. When all

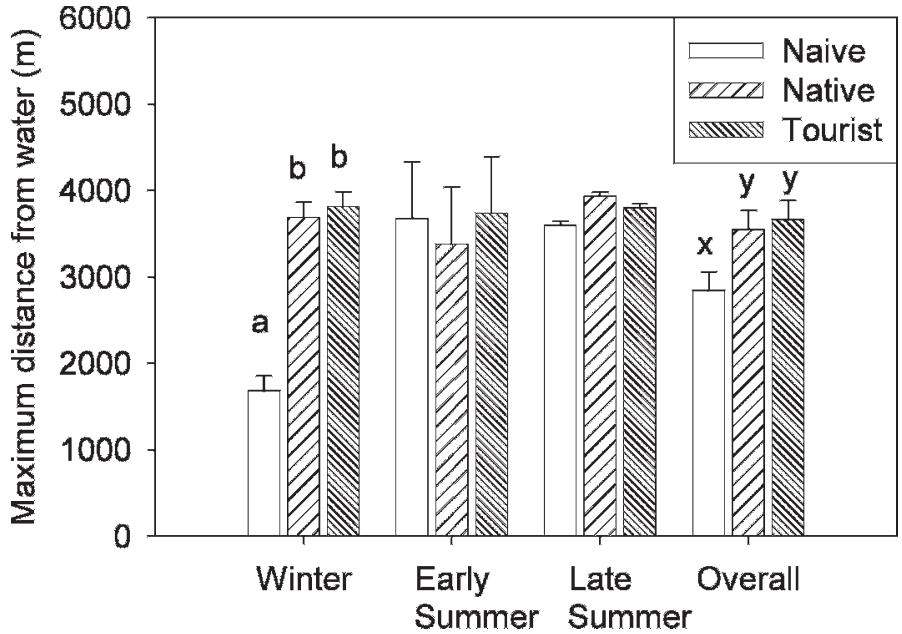

Figure 3. Maximum distance from water of global positioning system (GPS)-collared cows that were born and raised in a subtropical area (naïve), raised and remained in the Chihuahuan Desert (native), and were born and raised in the desert but were moved to a subtropical area for $3 \mathrm{yr}$ prior to the study (tourist). Distances represent maximum distance from water by randomly selected cows in each group during an 8-10-d period in each pasture during the winter (January and early February 2006), early summer (May and early June 2006), and late summer (August and early September 2006) sessions. Data from all three sessions were pooled and evaluated with the use of a repeated-measures analysis to provide an indication of an overall response. Values with different letters within a session differ (a,b, $P<0.05$ or $\mathrm{x}, \mathrm{y}, P<0.10$ ). Error bars represent standard error.

sessions were pooled, native cows spent a smaller $(P=0.06)$ percentage of time at water $(10.53 \% \pm 3.93 \mathrm{SE})$ than cows who did not graze continuously in the Chihuahuan Desert (naïve and tourist pooled). Native cows had longer $(P=0.10)$ bouts away from water $(7.13 \mathrm{~h} \pm 3.34 \mathrm{SE})$ than the pooled value of naïve and tourist cows (Table 3). Native cows had multiple bouts away from water lasting from $24 \mathrm{~h}$ to $48 \mathrm{~h}$ during each session. In addition, naïve cows tended to spend more $(P=0.10)$ time at water $(8.49 \% \pm 3.93 \mathrm{SE})$ than cows who were raised in the desert (native and tourist pooled).

\section{Diet Quality}

Interim Between Sessions. When cows were fed the same hay in pens, CP and DOM determined from fecal near-infrared spectroscopy was similar $(P>0.15)$ for the naïve, native, and tourist cows. Individual cows within a group were not a significant source of variation when fed the same diet.

Winter. Naïve cows selected a diet that was lower $(P=0.02)$ in CP than the other cows during the winter session (Fig. 5). There were no differences between native and tourist cows $(P>0.20)$ for CP. Diet DOM was similar $(P=0.63)$ for all three groups (Fig. 6).

Early Summer. In the early summer session, naïve cows selected a diet that was 1.78 percentage points \pm 0.35 SE lower in CP $(P=0.04)$ than the cows raised in the Chihuahuan Desert (moved and native pooled). Diet DOM was similar $(P=0.73)$ for all cows. 


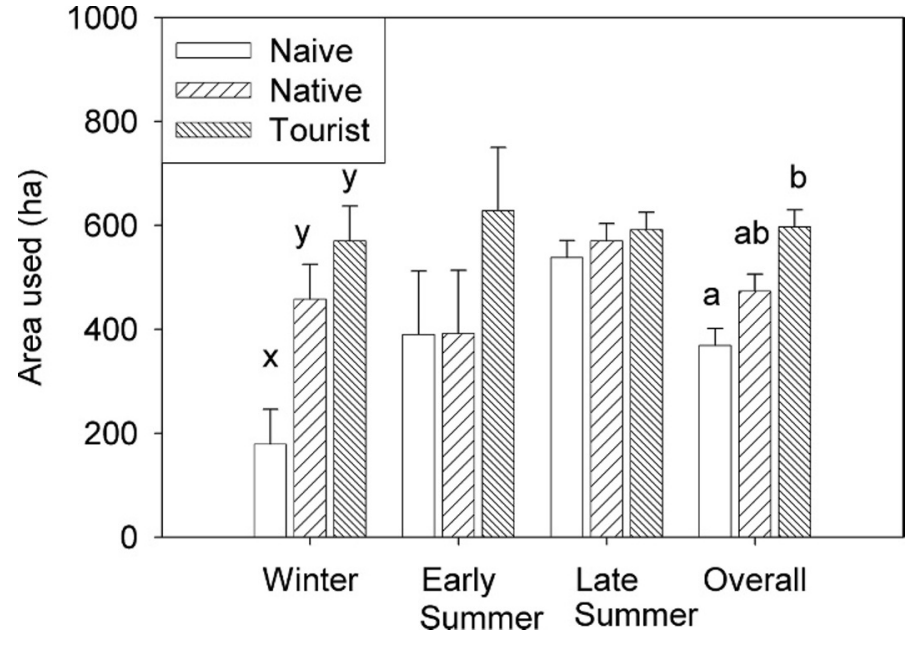

Figure 4. Area used by global positioning system (GPS)-collared cows that were born and raised in a subtropical area (naïve), raised and remained in the Chihuahuan Desert (native), and were born and raised in the desert but were moved to a subtropical area for $3 \mathrm{yr}$ prior to the study (tourist). Values represent the mean area (ha) contained within a minimum convex polygon from all GPS locations recorded from randomly selected cows in each group during 8-10-d periods in each pasture during the winter (January and early February 2006), early summer (May and early June 2006), and late summer (August and early September 2006) sessions. Data from all three sessions were pooled and evaluated with the use of a repeated-measures analysis to provide an indication of an overall response. Values with different letters within a session differ (a,b, $P<0.05$ or $\mathrm{x}, \mathrm{y}, P<0.10)$. Error bars represent standard error.

Late Summer Diet Quality. During late summer, native cows tended to select a diet that was lower $(P=0.07)$ in $\mathrm{CP}$ than cows that did not spend their entire life in the Chihuahuan Desert. For this contrast, the difference was 1.59 percentage points \pm 0.44 SE. Diet $\mathrm{CP}$ tended to be higher $(P=0.07)$ for naive cows than for cows raised at the CDRRC. The difference between diet $\mathrm{CP}$ of naïve cows and the other groups was 1.61 percentage points $\pm 0.45 \mathrm{SE}$. Native cows selected a diet that was 3.39 percentage points $\pm 0.84 \mathrm{SE}$ lower in DOM $(P=0.06)$ than the other two groups (pooled). Diet DOM for naïve cows was 3.44 percentage points $\pm 0.85 \mathrm{SE}$ greater $(P=0.06)$ than for cows raised in the Chihuahuan Desert.

\section{DISCUSSION}

In contrast to our expectations, naïve cows did not explore the pasture when first released into the CDRRC. Instead, naïve cows remained close to water and a small area (approximately 2 ha) of vine mesquite (Panicum obtusum H.B.K.) located about $200 \mathrm{~m}$ from water for 8 consecutive days. Anderson and Urquhart (1986) reported distance traveled by cattle when released into a new pastures in the Chihuahuan Desert was higher than subsequent levels and attributed this change as exploratory behavior similar to that described by Gluesing and Balph (1980). Cows that had been moved away from the Chihuahuan Desert to a subtropical environment for $3 \mathrm{yr}$ readily traveled from water and used a large area throughout the study. However, native cows that remained in desert conditions spent the most time at locations far from water compared to cows that had spent time in subtropical conditions. Prior to the study, naive cows typically grazed pastures in Leona, Texas that were 33 ha or less in size. Launchbaugh and Howery (2005) stated that experience and learning early in life likely affect both diet selection and movement patterns during grazing. Howery et al. (1998) found that daughters of cows that grazed uplands also grazed uplands and similarly cows that grazed in riparian areas were usually daughters of cows that spent more time in riparian areas. In the same study, heifer calves that were cross fostered used areas similar to their foster mother rather than their biological mother, which suggests that experience early in life can affect grazing patterns later in life. Results from this study suggest that previous experience with extensive Chihuahuan Desert pasture early in life may have contributed to the willingness of Brangus cows to travel away from water consistently. Both native and tourist cows readily used areas far from water. However, recent experience (within the last $3 \mathrm{yr}$ ) may also play a role in movement patterns in extensive desert pastures. Native cows tended to graze and use areas farther from water than tourist cows. The move to a novel location may also have elicited a temporary fear response from the naïve cows. Studies examining the "landscape of fear" suggest that animals may sacrifice traveling longer distances to find new forage resources when those areas may have a greater likelihood of danger (Brown et al. 1999; Laundré et al. 2001; Searle et al. 2008).

Contrary to what might be expected, differences among groups in the average distance from water were not the result of the distance that cows walked each day. Cows from each group traveled roughly the same distance each day. Instead, time spent away from water is the likely behavioral mechanism that resulted in differences between groups in the average distance to water. Native cows tended to spend more of their time away from water during the study. All cows spent a similar length of time at water, but native cows often spent periods of 24-48 h away from water. Naïve and tourist cows rarely spent more than $24 \mathrm{~h}$ away from water. Perhaps the continuous exposure to Chihuahuan Desert conditions allowed these cows to remain away from water for longer periods. Differences in time spent away from water between native and naïve animals could result from alternative strategies during foraging (a behavioral response) or perhaps from physiological adaptation. Macfarlane et al. (1971) suggested that animals with lower water turnover may survive longer in desert conditions. In addition, Ahmed and El Hadi (1996) found that desert-adapted cattle retained more water in their bodies than cattle adapted to more mesic conditions when exposed to high temperatures without water. The role of experience on physiological and behavioral adaptation of livestock to desert conditions in extensive pastures needs additional study.

All cows regularly traveled over $3.2 \mathrm{~km}$ from water even during the summer when temperatures were over $35^{\circ} \mathrm{C}$. Holechek (1988) suggested that areas between $1.6 \mathrm{~km}$ and $3.2 \mathrm{~km}$ from water be stocked with half of the animals recommended for areas less than $1.6 \mathrm{~km}$ from water and that areas over $3.2 \mathrm{~km}$ from water should be considered ungrazable. Similar to reports by Winder et al. $(1996,2000)$, results from this study suggest that Brangus cows are well adapted to desert conditions and can readily travel through relatively gentle 
Table 3. Mean distance traveled, number of trips to water each day, time spent at water, and time spent away from water for naïve, native, and cows that were moved from the Chihuahuan Desert to Texas for 3 yr (tourist) based on tracking data. Cattle were tracked during the winter (JanuaryFebruary 2006), early summer (May-June 2006), and late summer (August-September 2006). ${ }^{1}$

\begin{tabular}{|c|c|c|c|c|c|}
\hline \multirow[b]{2}{*}{ Attribute } & \multirow[b]{2}{*}{ Summer } & \multicolumn{3}{|c|}{ Experience } & \multirow[b]{2}{*}{ SE } \\
\hline & & Naïve & Native & Tourist & \\
\hline \multirow[t]{4}{*}{ Distance traveled $\left(\mathrm{km} \cdot \mathrm{d}^{-1}\right)$} & Winter & 4.59 & 6.16 & 5.65 & 0.72 \\
\hline & Early summer & 7.22 & 8.03 & 9.26 & 0.72 \\
\hline & Late summer & 10.00 & 8.99 & 8.97 & 1.49 \\
\hline & Sessions pooled & 7.28 & 7.73 & 7.96 & 0.54 \\
\hline \multirow[t]{4}{*}{ Trips to water (trips $\cdot d^{-1}$ ) } & Winter & 1.34 & 0.85 & 1.09 & 0.16 \\
\hline & Early summer & 1.79 & 1.58 & 1.70 & 0.06 \\
\hline & Late summer & 1.27 & 1.10 & 1.72 & 0.24 \\
\hline & Sessions pooled & 1.43 & 1.13 & 1.50 & 0.13 \\
\hline \multirow[t]{4}{*}{ Time at water $\left(\mathrm{h} \cdot\right.$ bout $\left.^{-1}\right)$} & Winter & 7.62 & 7.07 & 3.82 & 1.94 \\
\hline & Early summer & 6.15 & 5.03 & 5.98 & 0.67 \\
\hline & Late summer & 2.35 & 1.74 & 4.73 & 1.37 \\
\hline & Sessions pooled & 5.37 & 4.40 & 5.37 & 0.55 \\
\hline \multirow[t]{4}{*}{ Time away from water $\left(h \cdot\right.$ bout $\left.^{-1}\right)$} & Winter & 10.14 & 23.71 & 17.49 & 4.61 \\
\hline & Early summer & 7.71 & 11.25 & 9.07 & 1.28 \\
\hline & Late summer & 14.22 & 18.95 & 7.72 & 3.84 \\
\hline & Sessions pooled & 10.69 & 18.19 & 11.43 & 2.77 \\
\hline \multirow[t]{4}{*}{ Percentage of time at water (\%) } & Winter & 46.59 & 26.84 & 16.34 & 14.28 \\
\hline & Early summer & 41.39 & 28.40 & 38.27 & 7.68 \\
\hline & Late summer & 13.93 & 8.61 & 34.43 & 10.28 \\
\hline & Sessions pooled & $33.97 \times$ & $21.28 \mathrm{y}$ & $29.67 x y$ & 3.21 \\
\hline
\end{tabular}

${ }^{1}$ Values with different letters within a session differ $(P<0.10)$.

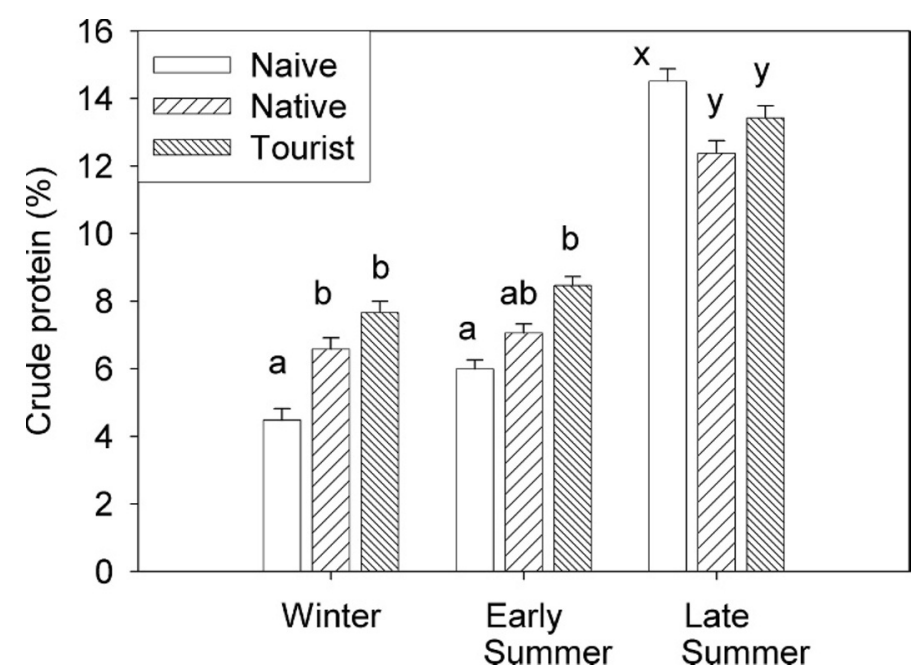

Figure 5. Estimated crude protein concentration of diets from cows that were born and raised in a subtropical area (naïve), raised and remained in the Chihuahuan Desert (native), and were born and raised in the desert but were moved to a subtropical area for 3 yr prior to the study (tourist). Means represent values estimated from fecal samples of all cows in each group during 8-10-d periods in each pasture during the winter (January and early February 2006), early summer (May and early June 2006), and late summer (August and early September 2006) sessions. Fecal near-infrared spectroscopy was used to estimate diet crude protein (Lyons and Stuth 1992). Values with different letters within a session differ $(\mathrm{a}, \mathrm{b}, P<0.05$ or $\mathrm{x}, \mathrm{y}, P<0.10)$. Error bars represent standard error.

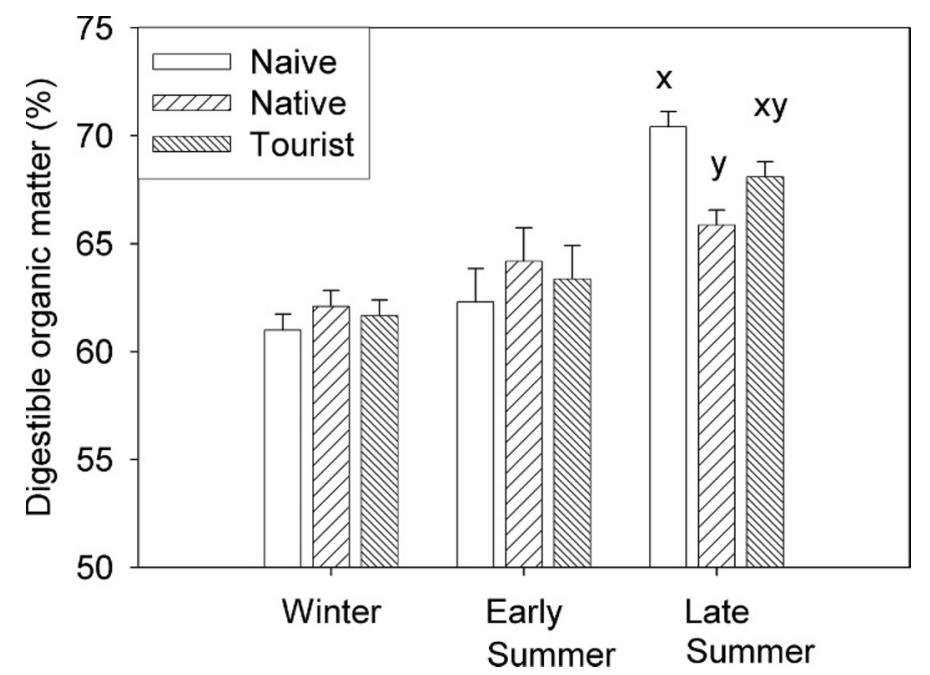

Figure 6. Estimated digestible organic matter concentration of diets from cows that were born and raised in a subtropical area (naive), raised and remained in the Chihuahuan Desert (native), and were born and raised in the desert but were moved to a subtropical area for 3 yr prior to the study (tourist). Means represent values estimated from fecal samples of all cows in each group during 8-10-d periods in each pasture during the winter (January and early February 2006), early summer (May and early June 2006), and late summer (August and early September 2006) sessions. Fecal near-infrared spectroscopy was used to estimate diet digestible organic matter (Lyons and Stuth 1992). Values with different letters within a session differ $(x, y, P<0.10)$. Error bars represent standard error. 
terrain and use areas greater than $1.6 \mathrm{~km}$ from water and ever farther than $3.2 \mathrm{~km}$ from water during winter and summer seasons.

Cows that were raised in the Chihuahuan Desert selected higher-quality diets than naïve cows during drought conditions. Their experience in desert conditions may have helped cows locate forages with more CP. Recent experience of native cows (within the last $3 \mathrm{yr}$ ) did not appear to provide any additional benefit in selecting a higher quality diet compared to cows that were moved away for 3 yr. Early learning and imprinting have long-term impacts on diet selection that may be more persuasive than relatively recent experiences (Provenza and Balph 1988; Distel and Provenza 1991; Wiedmeier et al. 2002). When forage availability and quality was high following unusually heavy monsoon rains in late summer, treatment differences were reduced but naïve cows selected the highestquality diets. Perhaps the naïve cows' experience with the more mesic conditions of the subtropics allowed them to choose plants with high forage quality readily when such plants were available. In contrast, cows from the desert may have chosen plants that were more nutritious in dry conditions but were not experienced in selecting the most nutritious plants when overall forage quality was high. Selection of a diet that was slightly lower in quality should not have adversely impacted the native or tourist cows during late summer, because all diets exceeded nutritional requirements (National Research Council 1996) in that session.

Although differences in movement patterns and diet selection between experience groups were identified, no measurable differences in cow weights were observed. Cows were weighed after being herded and sometimes hauled up to $10 \mathrm{~km}$ in a livestock trailer to corrals and scales. Consequently, practices that can minimize individual animal differences in gut fill, such as fasting or holding cattle away from water overnight, could not be used because of these logistical constraints. The resultant variation in weights and the relatively short time frame between measurements likely reduced our ability to detect differences in weight chances among cows of varying experience. In addition, cattle weights are often similar in the Chihuahuan Desert conditions of the CDRRC even though management differs. Thomas et al. (2007) found that light and conservative stocking levels affected Brangus cow weights at the CDRRC in the spring, but not in the fall. Winder et al. (2000) found that calf weaning weights were similar in pastures at CDRRC that were stocked at conservative and moderate levels. In contrast, pregnancy rates and calf weaning weights suggest that native cows performed better than tourist and especially naïve cows. Pregnancy rates of native cows $(100 \%)$ were even higher than the $88 \%$ to $93 \%$ levels reported by Thomas et al. (2007) for Brangus cows at the CDRRC, but pregnancy rates for the tourist and naïve cows were lower. Average 205-d calf weaning weights in this study were lower than the $270 \mathrm{~kg} \pm 8 \mathrm{SE}$ reported by Thomas et al. (2007) for the CDRRC. The average weaning weight for native cows was $218 \mathrm{~kg} \pm 8 \mathrm{SE}$ and $161 \mathrm{~kg} \pm 11$ SE for naïve cows. Comparisons between experience groups for pregnancy rates and weaning weights in this study are partially confounded with pasture because during the 60-d interim between the early and late summer sessions each group grazed separate pastures at the CDRRC. Otherwise, cows and calves were treated as similarly as possible. Stocking levels were very light during the interim between early and late summer sessions $\left(>62 \mathrm{ha} \cdot \operatorname{cow}^{-1}\right)$, and forage availability should not have been limiting. Pastures used for this interim contained similar forage species as those in study pastures and were selected to be as homogeneous as possible given restrictions from other studies.

Winder et al. (1996) contributed part of the observed differences in diet selection among cows in the Chihuahuan Desert to their willingness to graze areas far from water. Cows that grazed areas far from water in that CDRRC study had greater access to preferred plants. In this study, the willingness of native cows (and, to a lesser degree, tourist cows) to remain farther from water may have allowed them to select more preferred plants and higher quality forage more readily than naïve cows when forage quality was low during drought conditions. Results from this study are in agreement with anecdotal observations of nearby ranchers and recommendations of Provenza (2003) that experienced cattle can forage more efficiently than naïve animals. Managers should consider the degree that livestock are adapted and experienced to local conditions when calculating stocking rates and developing grazing management plans.

\section{IMPLICATIONS}

Brangus cattle are well adapted to desert conditions, and even naïve Brangus cows raised in radically different environmental conditions can readily learn to forage in extensive Chihuahuan Desert pastures. However, cows exposed to desert conditions throughout life may continue to have an advantage over naive animals. Ranchers using desert rangelands should stock at levels that will allow them to retain at least a core herd of cows adapted to their environmental conditions under drought conditions so that they can produce their own replacements. If replacements must be purchased, animals should be selected from herds that were developed with forages and environmental conditions similar to their location. However, with all sampling confined to a small number of animals, application of these findings to different populations and environments should be made with some reservations.

\section{ACKNOWLEDGMENT}

The authors would like to thank the Mound Creek Ranch in Leona, Texas, for its cooperation in this study.

\section{LITERATURE CITED}

Ahmed, M. M. M., And H. M. El Hadı. 1996. Water metabolism and dehydration in two types of cattle given poor and good quality roughages. Journal of Arid Environments 34:225-233.

Anderson, D. M., and N. S. Urquhart. 1986. Using digital pedometers to monitor travel of cows grazing and rangeland. Applied Animal Behaviour Science 16:11-23.

Balley, D. W., And F. D. Provenza. 2008. Mechanisms determining large-herbivore distribution. In: H. H. T. Prins and F. van Langevelde [EDS.]. Resource ecology: spatial and temporal dynamics of foraging. Dordrecht, Netherlands: Springer. p. 7-28. 
Beef Improvement Federation. 2002. Guidelines for uniform beef improvement programs. 8th ed. Athens, GA, USA: Beef Improvement Federation (BIF). 161 p. Available at http://beefimprovement.org/library/06guidlines.pdf. Accessed 19 November 2008.

Brown, J. S., J. W. Laundré, and M. GuRung. 1999. The ecology of fear: optimal foraging theory, game theory, and torphic interactions. Journal of Mammalogy 80:385-399.

Distel, R. A., and F. D. Provenza. 1991. Experience early in life affects voluntary intake of blackbrush by goats. Journal of Chemical Ecology 17:431-450.

Ganskopp, D. C., AND D. D. Johnson. 2007. GPS error in studies addressing animal movements and activities. Rangeland Ecology and Management 60:350-358.

Gluesing, E. A., And D. F. BalPH. 1980. An aspect of feeding behaviour and its importance to grazing systems. Journal of Range Management 33:426-427.

HolecheK, J. L. 1988. An approach for setting the stocking rate. Rangelands 10:10-14.

Howery, L. D., F. D. Provenza, and R. E. Banner. 1998. Social and environmental factors influence cattle distribution. Applied Animal Behaviour Science $55: 231-244$

Howery, L. D., F. D. Provenza, R. E. Banner, and C. B. Scott. 1996. Differences in home range and habitat use among individuals in a cattle herd. Applied Animal Behaviour Science 49:305-320.

Johnson, D. D., AND D. C. Ganskopp. 2008. GPS collar sampling frequency: effects on measures of resource use. Rangeland Ecology and Management 61:226-233.

Launchbaugh, K. D., and L. D. Howery. 2005. Understanding landscape use pattern of livestock as a consequence of foraging behavior. Rangeland Ecology and Management 58:99-108.

Laundré, J. W., L. Heranández, and K. B. Altendorf. 2001. Wolves, elk, and bison: reestablishing the "landscape of fear" in Yellowstone National Park, U.S.A. Canadian Journal of Zoology 79:1401-1409.

Littell, R. C., G. A. Milliken, W. W. Stroup, and R. D. Wolfinger. 1996. SAS System for Mixed Models. Cary, NC, USA: SAS Institute Inc.

LYons, R. K., AND J. W. STUTH. 1992. Fecal NIRS equations for predicting diet quality of free-ranging cattle. Journal of Range Management 44:238-244.

Macfarlane, W. V., B. Howard, H. Hains, H. P. J. Kennedy, and C. M. Sharp. 1971. The hierarchy of water and energy turnover of mammals living in desert. Nature (London) 234:483-484.
Mathis, C. P., J. E. Sawyer, and R. Parker. 2002. Managing and feeding beef cows using body condition scores. Las Cruces, NM, USA: New Mexico State University Cooperative Extension Circular 575. 10 p. Available at: http://www. cahe.nmsu.edu/pubs/_circulars/CR575.pdf. Accessed 18 November 2008.

Moen, R., J. Pastor, and Y. Cohen. 1997. Accuracy of GPS telemetry collar locations with differential correction. Journal of Wildlife Management 61:530-539.

National Research Councli. 1996. Nutrient requirements of beef cattle. 7th ed. Washington, DC, USA: National Academy Press. 242 p.

Natural Resources Conservation Service. 2009. Ecological Site Descriptions: Major Land Resource Area 42, Chihuahuan Desert Shrubs 42.2. Albuquerque, NM, USA: USDA Natural Resources Conservation Service. Available at: http://esis.sc.egov.usda.gov/esis_report/fsReport.aspx?approved=yes\&id= R042XB010NM. Accessed 18 June 2009.

ProvenzA, F. D. 2003. Foraging behavior: managing to survive in a world of change. Logan, UT, USA: Utah State University. 63 p.

Provenza, F. D., and D. F. Balph. 1988. Development of dietary choice in livestock on rangelands and its implications for management. Journal of Animal Science 66:2356-2368.

SAS [COMPUTER PROGRAm]. 2002. SAS Version 9.1.2. Cary, NC, USA: SAS Institute, Inc.

Searle, K. R., C. J. Stokes, and I. J. Gordon. 2008. When foraging and fear meet: using foraging hierarchies to inform assessments of landscapes of fear. Behavioral Ecology 19:475-482

Thomas, M., J. Hawkes, G. Khumalo, and J. Holechek. 2007. Brangus cow-calf performance under two stocking levels on Chihuahuan desert rangeland. Rangeland Ecology and Management 60:110-114.

Wiedmeier, R. D., F. D. Provenza, and E. A. Burritt. 2002. Exposure to ammoniated wheat straw as suckling calves improves performance of mature beef cows wintered on ammoniated wheat straw. Journal of Animal Science 80: 2340-2348.

Winder, J. A., C. C. Bailey, M. G. Thomas, and J. L. Holechek. 2000. Effect of breed and stocking rate on Chihuahuan Desert cattle production. Journal of Range Management 53:32-38.

Winder, J. A., D. A. Walker, and C. C. Balley. 1996. Effect of breed on botanical composition of cattle diets on Chihuahuan desert range. Journal of Range Management 49:209-214. 